\title{
GEOLOGICAL NOTE
}

\section{Global Aridity during the Early Miocene? A Terrestrial Paleoclimate Record from the Ebro Basin, Spain}

\author{
Jessica M. M. Hamer, ${ }^{1}$ Nathan D. Sheldon, ${ }^{2}$ and Gary J. Nichols ${ }^{3}$ \\ Geology Department, Royal Holloway, University of London, Egham, Surrey TW20 OEX, United Kingdom \\ (e-mail: j.hamer@gl.rhul.ac.uk)
}

\begin{abstract}
A B S T R A C T
Paleosols are an important tool in the paleoclimatic and paleoenvironmental interpretation of continental deposits and can provide a high-resolution proxy for paleoclimate. Results from geochemical climofunctions applied to Early Miocene strata exposed in the Ebro Basin, Spain, demonstrate that mean annual precipitation was the dominant control on paleosol type and indicate that the paleoclimate was considerably wetter during the Early Miocene, by up to $1150 \mathrm{~mm} \mathrm{yr}^{-1}$, in comparison to modern values, placing it in a subhumid climatic regime rather than an aridsemiarid regime as previously suggested by sedimentological and paleontological approaches. By making comparisons with published data on paleoclimate during the Early Miocene, this article stresses the importance of regional climatic changes in global paleoclimatic interpretation.
\end{abstract}

\section{Introduction}

Paleosols are an effective and underused proxy for paleoclimatic interpretation, and their use, particularly when there is a dearth of other proxies, can provide quantitative and detailed paleoclimatic information. By using a combination of detailed outcrop studies and geochemical analyses, this article describes paleoclimatic trends within the Early Miocene that are preserved in distal fluvial deposits within the Huesca Fluvial Distributary System, Ebro Basin in northern Spain (fig. 1).

Paleoenvironmental and paleoclimatic data for the Early Miocene of the Ebro Basin are limited. Studies of Late Oligocene fluvial and lacustrine deposits of the Calf and Mequinenza sequences, which form part of a separate fluvial system found in the southeastern Ebro Basin, have suggested an arid to semiarid climate, based on sedimentary and paleobiological observations (e.g., Cabrera et al. 2002). Similarly, micromammal biostratigraphy based on faunal composition has provided some low-resolution paleoclimatic information within

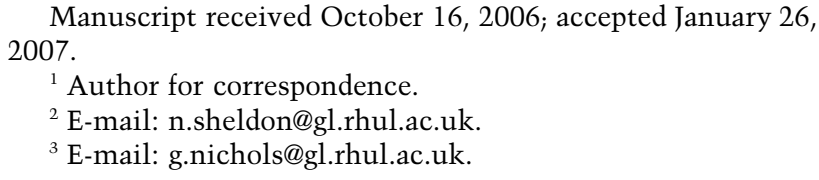

${ }^{3}$ E-mail: g.nichols@gl.rhul.ac.uk.

the Huesca system that suggests decreasing temperatures and increasing aridity from the Late Oligocene to the Middle-Late Miocene (Álvarez Sierra et al. 1990). Field observations made by Nichols and Hirst (1998) conversely infer a relatively humid climate during the Late Oligocene-Early Miocene of the Huesca Fluvial Distributary System, which was not found during this study. However, this conclusion is based on the absence of calcrete profiles and, ambiguously, on the identification of Vertisol-like paleosols, which have shown to be absent from sections studied (Hamer et al. 2007). A decrease in aridity is suggested from studies within lake deposits of the central Ebro Basin during the Early to Middle Miocene (e.g., Arenas and Pardo 2000).

A dearth of organics and pedogenic carbonates has meant that paleoclimatic interpretations of Late Oligocene-Early Miocene clastic sediments within the Ebro Basin have been based on field observations alone or are of low temporal resolution (e.g., Álvarez Sierra et al. 1990; Nichols and Hirst 1998; Cabrera et al. 2002). This article provides a new, higher-resolution proxy that refines previous interpretations of the terrestrial paleoclimate record of the Ebro Basin and highlights the importance 


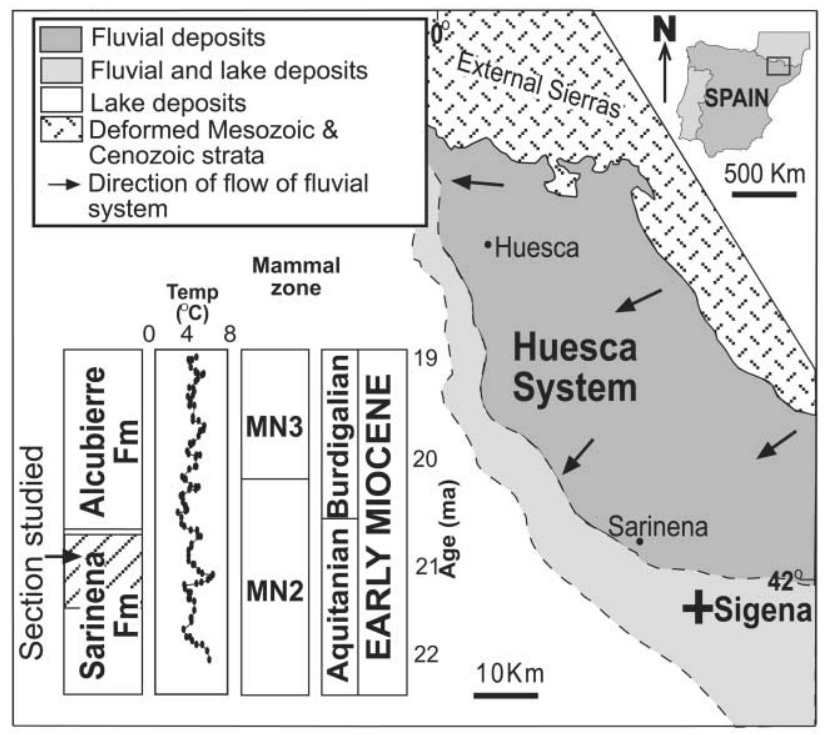

Figure 1. Field map and summary stratigraphy. The map is modified after Nichols and Hirst (1998). Stratigraphy is based on previous work (Agustí et al. 2001; Pérez-Rivarés et al. 2002). Temperature values are calculated from $\delta^{18} \mathrm{O}$ of benthic marine foraminifera and use a five-point running mean (Zachos et al. 2001).

of paleosols as paleoclimatic indicators when other proxies are absent.

\section{Geological Setting and Paleogeography}

The Ebro Basin (fig. 1) is situated on the northeastern part of the Iberian Peninsula and occupies an area of more than $45,000 \mathrm{~km}^{2}$ (Puigdefàbregas et al. 1992). Paleomagnetic data and palinspastic plate reconstructions indicate that the Ebro Basin had a paleolatitude slightly south $\left(37^{\circ} \mathrm{N}\right)$ of its present latitude $\left(40^{\circ} \mathrm{N}\right.$; Van der Voo 1993; Barberà et al. 2001). Fluvial systems that prograded into a central ephemeral lake (fig. 1) were identified by Hirst and Nichols (1986) and separated into the Luna and Huesca distributary systems. The central lake was generally only a few meters deep and never exceeded $15 \mathrm{~m}$ in depth (Cabrera et al. 2002). It underwent numerous retreats and expansions, which resulted in lake incursions over the alluvial plain, covering distances of more than $15 \mathrm{~km}$ (Cabrera et al. 2002). Alluvial mudstones and sandstones of the Huesca Distributary System are exposed at Sigena and are part of the Sariñena Formation (Quirantes 1978; Arenas et al. 1997, 2001). Absolute age control is provided by a combination of paleomagnetic and biostratigraphic data. The stratigraphic position was determined using previous magnetostra- tigraphic studies in the Sigena area (Albalatillo section) by Pérez-Rivarés et al. (2002) in concert with identification of mammal zones by Agustí et al. (2001). The age was further constrained by assuming an average bulk sedimentation rate of $10.7 \mathrm{~cm}$ $\mathrm{ka}^{-1}$ from an overlying marker bed. The sedimentation rate was calculated from magnetic reversals in alluvial successions in the study area (PérezRivarés et al. 2002), but it should be noted that floodplain sedimentation rates are commonly variable and the assigned sedimentation rate may be erroneous. Paleosols are identified within the Huesca Fluvial Distributary System interbedded with and overprinting channel, overbank, and lacustrine sediments.

\section{Methods}

A 28-m stratigraphic section was measured within the distal parts of the Huesca Fluvial Distributary System (fig. 2). Paleosols in this section were excavated to a depth of $30 \mathrm{~cm}$ to provide a fresh surface for description and sampling. Samples were collected from Bt (argillic) and Bw (colored) horizons. Paleosols $(n=44)$ were classified into pedotypes based on field observations including horizon thickness, bedding, and Munsell color from dry samples (Retallack 2001). Paleosol characteristics are comparable to those of modern soils and therefore, using the U.S. Department of Agriculture taxonomic system (Soil Survey Staff 1999), can be classified as Entisol-like, Inceptisol-like, and Alfisol-like (table 1).

The top of paleosol profiles was defined as the surface from which root traces emanate, and the base was defined by the first occurrence of unaltered parent material. Paleosol thickness ranged from 0.3 to $1.25 \mathrm{~m}$. Geochemical analysis for major elements, using powered whole-rock samples obtained from $\mathrm{Bt}$ and $\mathrm{Bw}$ horizons, was undertaken using an x-ray fluorescence spectrometer (Philips PW 1480) at Royal Holloway, University of London; results were collated as supplemental data.

\section{Paleoclimatic Reconstruction}

Despite an abundance of detrital carbonate within the paleosols studied, there is no indication of pedogenically formed carbonate (Nichols and Hirst 1998). Pedogenic carbonate is absent from soils receiving more than $760 \mathrm{~mm} \mathrm{yr}^{-1}$ precipitation (Royer 1999); however, this value varies with local evapotranspiration and seasonality (Royer 1999; Retallack 2000). Where pedogenic carbonate is absent, comparisons using the indices of weathering 


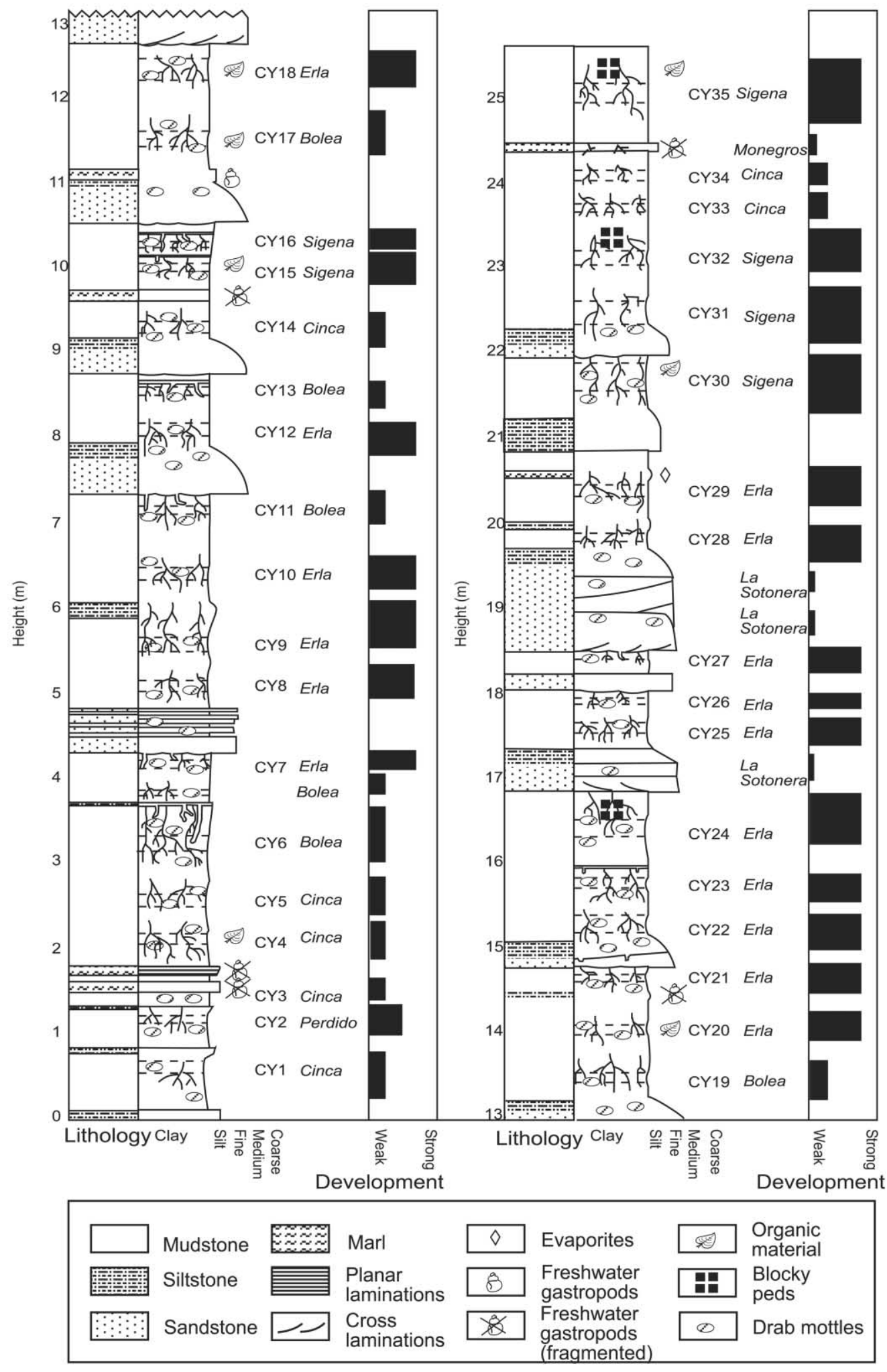

Figure 2. Stratigraphic log of the section studied. Pedotype names are allocated based on the description of Hamer et al. (2007). Soil development is based on qualitative field observations. 
Table 1. Description and Interpretation of Different Paleosols Found within the Studied Section

\begin{tabular}{|c|c|c|c|c|}
\hline \multirow[b]{2}{*}{ Pedotype } & \multirow{2}{*}{$\begin{array}{r}\text { Description } \\
\text { Diagnosis }\end{array}$} & \multicolumn{3}{|c|}{ Interpretation } \\
\hline & & $\begin{array}{l}\text { Soil type } \\
\left(\mathrm{USDA}^{\mathrm{a}}\right)\end{array}$ & Paleoclimate & Former vegetation \\
\hline Bolea & $\begin{array}{l}\text { Relict primary structure, } \\
\text { cambic and colored } \\
\text { (Bw) horizon; absence } \\
\text { of pedogenic carbonate }\end{array}$ & Inceptisol & $\begin{array}{l}\text { MAT } 13^{\circ} \mathrm{C}, \\
\text { MAP } 505 \mathrm{~mm} \mathrm{yr}^{-1}\end{array}$ & $\begin{array}{l}\text { Herbaceous vegetation, } \\
\text { low-stature plants }\end{array}$ \\
\hline Cinca & $\begin{array}{l}\text { Relict primary structure, } \\
\text { cambic and colored } \\
(\mathrm{Bw}) \text { horizon; absence } \\
\text { of pedogenic carbonate }\end{array}$ & Inceptisol & $\begin{array}{l}\text { MAT } 13^{\circ} \mathrm{C} \\
\text { MAP } 428 \mathrm{~mm} \mathrm{yr}^{-1}\end{array}$ & $\begin{array}{l}\text { Herbaceous vegetation, } \\
\text { low-stature plants }\end{array}$ \\
\hline Erla & $\begin{array}{l}\text { Argillic (Bt) horizon; ab- } \\
\text { sence of pedogenic } \\
\text { carbonate }\end{array}$ & Alfisol & $\begin{array}{l}\text { MAT } 12^{\circ} \mathrm{C} \\
\text { MAP } 975 \mathrm{~mm} \mathrm{yr}^{-1}\end{array}$ & $\begin{array}{l}\text { Open woodland com- } \\
\text { posed of herbaceous } \\
\text { vegetation, low-stature } \\
\text { plants, and small trees }\end{array}$ \\
\hline La Sotonera & $\begin{array}{l}\text { Relict bedding, sandy in } \\
\text { all horizons; absence of } \\
\text { pedogenic carbonate }\end{array}$ & Entisol & NA & Herbaceous vegetation \\
\hline Monegros & $\begin{array}{l}\text { Relict bedding, preserva- } \\
\text { tion of organic matter, } \\
\text { drab colors; absence of } \\
\text { pedogenic carbonate }\end{array}$ & Entisol & NA & $\begin{array}{l}\text { Reedlike } \\
\text { monocotyledons }\end{array}$ \\
\hline Perdido & $\begin{array}{l}\text { Argillic }(\mathrm{Bt}) \text { horizon, hue } \\
\text { >YR 2.5; absence of } \\
\text { pedogenic carbonate }\end{array}$ & Alfisol & $\begin{array}{l}\text { MAT } 13^{\circ} \mathrm{C} \\
\quad \text { MAP } 361 \mathrm{~mm} \mathrm{yr}^{-1}\end{array}$ & $\begin{array}{l}\text { Open woodland com- } \\
\text { posed of herbaceous } \\
\text { vegetation and low- } \\
\text { stature plants }\end{array}$ \\
\hline Sigena & $\begin{array}{l}\text { Argillic horizon }(\mathrm{Bt}) \text {, re- } \\
\text { doximorphic features; } \\
\text { absence of pedogenic } \\
\text { carbonate }\end{array}$ & Alfisol & $\begin{array}{l}\text { MAT } 11^{\circ} \mathrm{C} \\
\text { MAP } 951 \mathrm{~mm} \mathrm{yr}^{-1}\end{array}$ & $\begin{array}{l}\text { Open woodland com- } \\
\text { posed of herbaceous } \\
\text { vegetation, low-stature } \\
\text { plants, and small trees }\end{array}$ \\
\hline
\end{tabular}

Note. Table information adapted from Hamer et al. (2007). MAT = mean annual temperature; MAP = mean annual precipitation. ${ }^{a}$ U.S. Department of Agriculture Soil Survey Staff 1999.

of modern soils and their precipitation regimes can be applied (Sheldon et al. 2002; Sheldon 2003). Mean annual precipitation (MAP) can be related to the chemical index of alteration without potassium $(\mathrm{CIA}-\mathrm{K})$ and is calibrated for precipitation values between 200 and $1600 \mathrm{~mm} \mathrm{yr}^{-1}$ :

$$
\operatorname{MAP}\left(\mathrm{mm} \mathrm{yr}^{-1}\right)=221 e^{0.0197(\mathrm{CIA}-\mathrm{K})} \text {, }
$$

where CIA $-\mathrm{K}=100 \times\left[\mathrm{Al}_{2} \mathrm{O}_{3} /\left(\mathrm{Al}_{2} \mathrm{O}_{3}+\mathrm{CaO}+\right.\right.$ $\left.\left.\mathrm{Na}_{2} \mathrm{O}\right)\right]$ and $R^{2}=0.72$, with an error of $\pm 182 \mathrm{~mm}$ $\mathrm{yr}^{-1}$; results obtained with this method are consistent with independent estimates from other proxies, such as plant fossils (Sheldon et al. 2002; Sheldon and Retallack 2004). There is no field evidence to suggest that the MAP was out of this range (Sheldon et al. 2002).

Mean annual temperature (MAT) can be related to salinization for paleosols (Retallack 2001; Sheldon et al. 2002):

$$
\operatorname{MAT}\left({ }^{\circ} \mathrm{C}\right)=-18.5 S+17.3
$$

where $S=(\mathrm{mK}+\mathrm{mNa}) / \mathrm{mAl}$ and $R^{2}=0.37$, with a standard error of $\pm 4.4^{\circ} \mathrm{C}$. The error on this is substantial, and a more precise estimation for MAT can be derived for the Inceptisol-like paleosols with the following equation:

$$
\operatorname{MAT}\left({ }^{\circ} \mathrm{C}\right)=46.9 \mathrm{C}+4.0,
$$

where $C=\mathrm{mAl} / \mathrm{mSi}$ and $R^{2}=0.96$, with an error of $\pm 0.6^{\circ} \mathrm{C}$ (Sheldon 2006).

Reconstructed paleoclimate results indicate that during the early Miocene, the climate for the majority of the time was considerably wetter than the modern climate (fig. $3 D$ ). The modern climate of the Ebro Basin is Mediterranean continental with semiarid characteristics (Sirvent et al. 1997). Current MAP within the Ebro Basin is $320 \mathrm{~mm} \mathrm{yr}^{-1}$, and the MAT is $14^{\circ} \mathrm{C}$, with a seasonal range from $25^{\circ} \mathrm{C}$ in July to $4^{\circ} \mathrm{C}$ in January (Sirvent et al. 1997). The MAP values obtained from paleosols had a range of $330-1470 \pm 182 \mathrm{~mm} \mathrm{yr}^{-1}$ and a mean of $777 \mathrm{~mm} \mathrm{yr}^{-1}$ (fig. 3D). The MAT values from Inceptisol-like paleosols (eq. [3]) ranged from $10^{\circ}$ to $15^{\circ} \mathrm{C}$, with a mean value of $13.4^{\circ} \mathrm{C}\left(\mathrm{SD}=1.5^{\circ} \mathrm{C}\right)$. Alfisol-like paleosols (eq. [2]) had a range of $10^{\circ}-$ $12^{\circ} \mathrm{C}$ and a mean of $11.7^{\circ} \mathrm{C}\left(\mathrm{SD}=0.6^{\circ} \mathrm{C}\right)$. However, the error with the application of equation (2) is sub- 

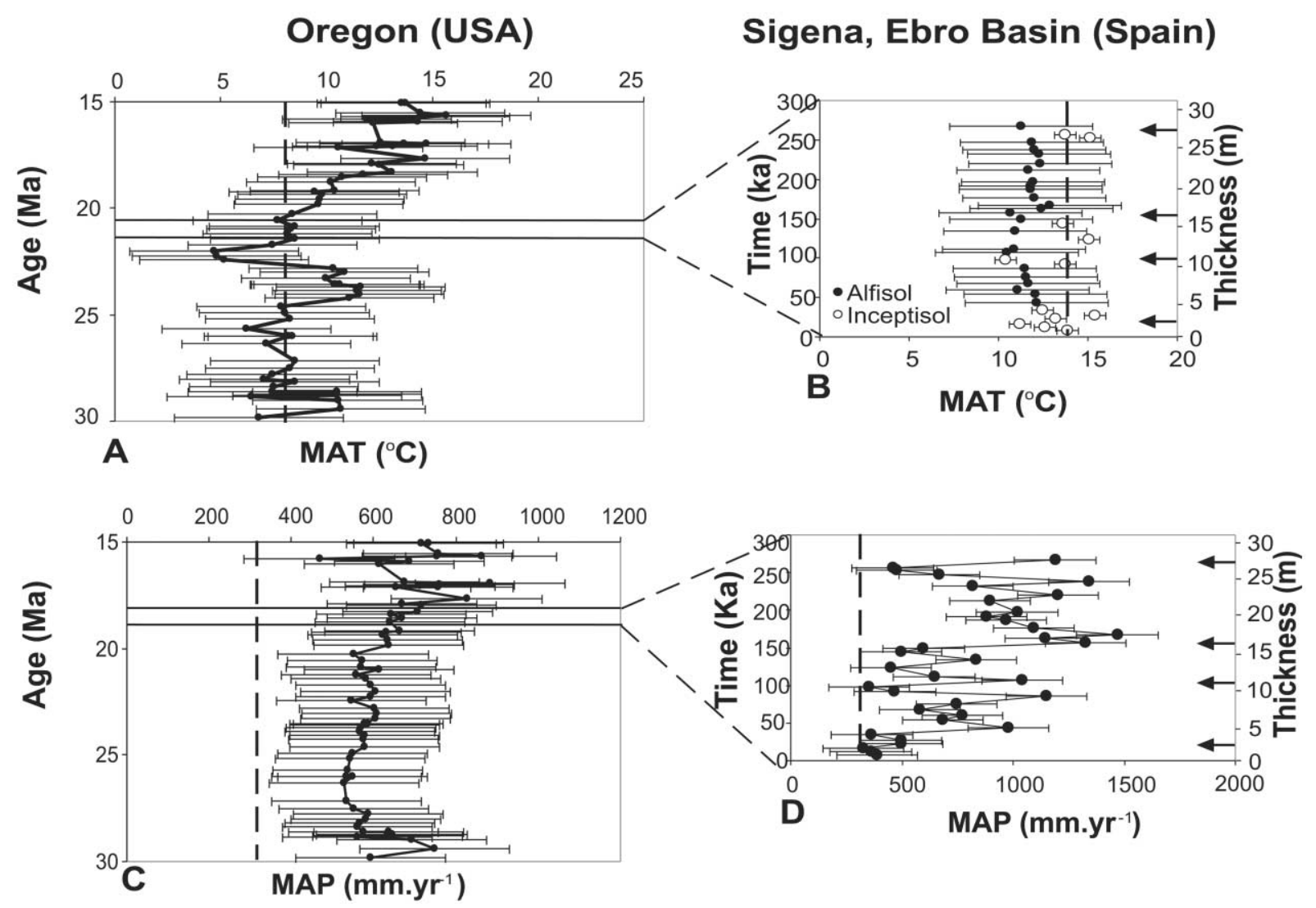

Figure 3. Paleoclimatic comparison of the data obtained from paleosols within the Sigena Canyon section, Spain, and the John Day Formation, Oregon (Retallack 2004). A, Estimates of mean annual temperature (MAT) from geochemical composition (eq. [2]), from the Late Oligocene-Middle Miocene of Oregon (Retallack 2004). B, Comparative MAT data from the Early Miocene, Ebro Basin, using equations (2), (3). C, Mean annual precitpitation estimates based on values of chemical index of alteration without potassium (eq. [1]), from Oregon (Retallack 2004). D, Sigena, Spain. Dashed vertical line indicates modern values; arrows indicate lake flood events as identified by shifts to lacustrine facies.

stantial and overlaps with values obtained from Inceptisol-like paleosols, suggesting minimal variation in MAT, both temporally and between the formation of Inceptisol-like and Alfisol-like paleosols. The more robust climofunction for Inceptisollike paleosols gives an overall slightly higher average MAT value $\left(13.4^{\circ} \mathrm{C}\right)$ in comparison to the climofunction for Alfisol-like paleosols $\left(11.7^{\circ} \mathrm{C}\right)$; this may be a reflection of the preferential development of Inceptisol soils during hot, more arid times, or it may be a result of the error within the climofunctions themselves.

\section{Discussion}

Paleosol Development and Climate. Based on field observations of paleosol type and Köppen's climate classification, the environment changed during the
Early Miocene from a semiarid herbaceous environment to a midlatitude deciduous open forest. During the $\sim 300$-ka period studied, there appears to be an $\sim 100$-ka cyclicity linked to lake incursions and paleosol development, with a general overall trend toward increased paleosol maturity up the section, changing from Inceptisol-like paleosols to Alfisol-like paleosols (fig. 2). It was found that variations in MAP appear to result in differentiation between Inceptisol-like and Alfisol-like paleosols (fig. 4C). This is unsurprising because the MAP climofunction used is dependent on the CIA - K, which is a measure of the degree of weathering within a soil (Maynard 1992), and modern Alfisols represent heavier weathering than Inceptisols (Soil Survey Staff 1999). An obvious control on the degree of chemical weathering, and one that would ultimately have an effect on calculated MAP val- 

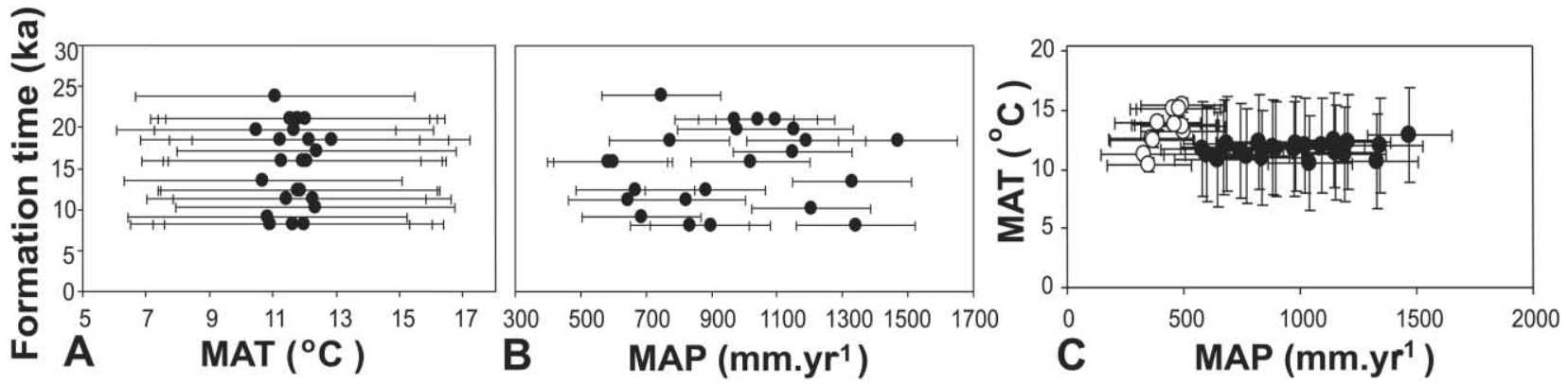

Figure 4. Mean annual temperature $\left(\mathrm{MAT}_{2} A\right)$ and mean annual precipitation $(\mathrm{MAP} ; B)$ are independent of paleosol formation time. Paleosol formation time is based on a chronofunction from data of Markewich et al. (1990). C, Control of MAP and MAT on paleosol type.

ues, is the time taken for soil formation (fig. $4 A$, $4 B$ ), because the effects of lower MAP over a long formation time could be indistinguishable from the effects of high MAP over a short period of time. However, it is possible to show that both MAP and MAT are independent of this by applying a chronofunction based on data of Markewich et al. (1990; fig. $4 A, 4 B$ ), which relates the thickness of the $\mathrm{Bt}$ horizon to the formation time:

$$
\begin{gathered}
\text { Formation time }(\mathrm{yr})= \\
17.7(\mathrm{Bt} \text { thickness })^{2}+645.8(\mathrm{Bt} \text { thickness }),
\end{gathered}
$$

where $R^{2}=0.87$ (e.g., Sheldon 2003). Therefore, because MAT is little changed (fig. $4 C$ ), the dominant control on soil formation appears to be precipitation and not parent material, soil organisms, topography, or time, which were all unchanged (Hamer et al. 2007).

Global Implications. The general consensus among researchers is that the Miocene was a time of relative global warmth and aridity interspersed with short-lived glaciations and that warm conditions peaked at the Middle Miocene climatic optimum (e.g., Zachos et al. 2001). The results from this study show a greater magnitude in relative MAP within the Ebro Basin compared to similar paleosol data from Oregon compiled by Retallack (2004) for the Early Miocene. This suggests that MAP was affected predominantly by regional rather than global climatic factors; larger variations can be seen relative to the mean at Sigena, in comparison to Oregon (fig. 5). Regional variations in paleoclimate are also seen near the Alps; paleofloristic data indicate a humid climate south of the Alps during the early Miocene and, conversely, a more arid climate in the northern Alps (Berger 1992). The $\delta^{18} \mathrm{O}$ values from deep-sea sediment cores from the Late Oligocene-Middle Miocene record a $4^{\circ}-6^{\circ} \mathrm{C}$ increase in bottom-water temperature in comparison to modern values (fig. $1 ; \mathrm{Za}$ chos et al. 2001). This is not reflected in the paleosol record from the Ebro Basin or the Oregon data produced by Retallack (2004), which show values similar to the modern MAT. This disparity between the continental and oceanic records of paleotemperature could be attributed to changes in terrestrial ice volume and oceanic salinity (Zachos et al. 2001).

The data presented here suggest that the idea of

\section{MAP Variation Oregon (USA) and Sigena, Ebro Basin (Spain)}

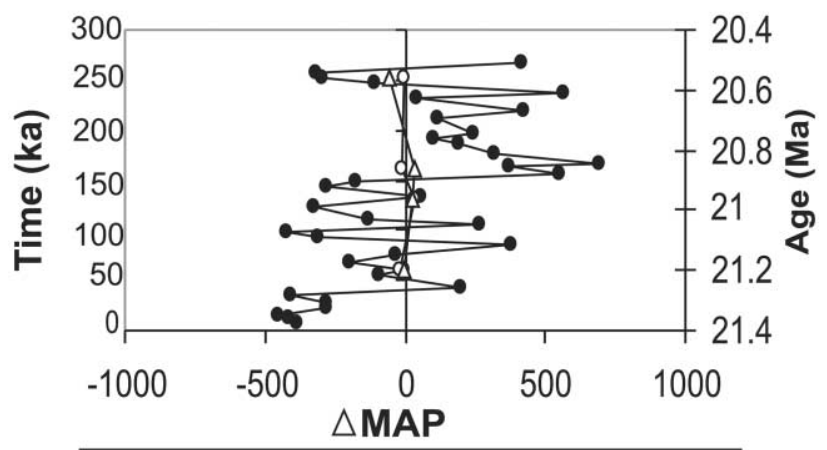

- Sigena, Ebro Basin Spain

-o- Oregon, USA. (Geochemical) Retallack, (2004)

$\triangle-$ Oregon, USA. (Bk depth) Retallack, (2004)

Figure 5. Variation of mean annual precipitation (MAP) in Oregon (Retallack 2004) and in Sigena, Spain. The values of $\triangle \mathrm{MAP}$ are calculated as the difference between the average and the value of an individual data point. Scale for Sigena is ka; scale for Oregon is Ma. 
global aridity and increased temperatures during the Early Miocene, relative to modern conditions, is a misconception and cannot be applied universally. Furthermore, the MAP estimates discussed here also suggest that the Ebro Basin had a highly variable water regime (including humid and subhumid intervals) and that previous work within the Ebro Basin, based on sedimentological observations describing the climate as permanently arid-semiarid (e.g. Cabrera et al. 2002) or subhumid (e.g., Nichols and Hirst 1998) can now be quantitatively confirmed.

\section{Conclusions}

Mean annual temperature comparisons between Oregon and the Ebro Basin during the Early Miocene suggest that, in both locations, paleotemperatures were similar to modern values and unchanging in contrast to deep-sea records. High MAP values relative to modern MAP are also comparable between Oregon and the Ebro Basin and were found to be the primary control on paleosol type at Sigena; these values differ significantly from previous interpretations of paleoprecipitation within the Ebro Basin. Given that the resolution of the Sigena data is significantly higher than that of the published data from Oregon, it is important to note that the Sigena section records climatic fluctuations of more than $700 \mathrm{~mm} \mathrm{yr}^{-1}$ in comparison with the mean, highlighting that regional variations in precipitation can be significant despite a consistent global climatic signal.

\section{A C K N O W L E D G M E N T S}

We are very grateful for the helpful comments made by M. Thirlwall and C. Arenas. This work was funded by a Natural Environment Research Council (NERC) studentship (J. M. M. Hamer) and an NERC grant (NE/D00021/1) to N. D. Sheldon.

\section{R E F E R E N C E S C I T E D}

Agustí, J.; Cabrera, L.; Garces, M.; Krijgsman, W.; Oms O.; and Pares, J. M. 2001. A calibrated mammal scale for the Neogene of western Europe: state of the art. Earth Sci. Rev. 52:247-260.

Álvarez Sierra, M. A.; Daams, R.; Lacomba, J. I.; López Martínez, N.; Van der Meulen, A. J.; Sesé, C.; and De Viser, J. 1990. Paleontology and biostratigraphy (micromammals) of the continental Oligocene-Miocene deposits of the north-central Ebro Basin (Huesca, Spain). Scr. Geol. 94:1-77.

Arenas, C.; Casanova, J.; and Pardo, G. 1997. Stable isotope characterization of the Miocene lacustrine systems of Los Monegros (Ebro Basin, Spain): palaeogeographic and palaeoclimatic implications. Palaeogeogr. Palaeoclimatol. Palaeoecol. 128:133-155.

Arenas, C.; Millán, H.; Pardo, G.; and Pocoví, A. 2001. Ebro Basin continental sedimentation associated with late compressional Pyrenean tectonics (north-eastern Iberia): controls on basin margin fans and fluvial systems. Basin Res. 13:65-89.

Arenas, P., and Pardo, G. 2000. Neogene lacustrine deposits of the north-central Ebro Basin, north-eastern Spain. In Gierlowski-Kordesch, E. H., and Kelts, K. R., eds. Lake basins through space and time. AAPG Stud. Geol. 46:395-406.

Barberà, X.; Cabrera, L.; Marzo, M.; Parés, J. M.; and Agustí, J. 2001. A complete terrestrial Oligocene magnetostratigraphy from the Ebro Basin, Spain. Earth Planet. Sci. Lett. 187:1-16.

Berger, J. P. 1992. Paleontologic de la Molasse de Suisse Occidentale, taxonomic, biostratigraphie, paleoecologie, paleogeographie et paleoclimatologie. Phd thesis, University of Fribourg, 405 p.
Cabrera, L.; Cabrera, M.; Gorchs, R.; and de las Heras, F. X. C. 2002. Lacustrine basin dynamics and organosulphur compound origin in a carbonate-rich lacustrine system (Late Oligocene Mequinenza Formation, SE Ebro Basin, NE Spain). Sediment. Geol. 148:289317.

Hamer, J. M. M.; Sheldon, N. D.; Nichols, G. J.; and Collinson, M. E. 2007. Late Oligocene-Early Miocene palaeosols of distal fluvial systems, Ebro Basin, Spain. Palaeogeogr. Palaeoclimatol. Palaeoecol. 247:220-235.

Hirst, J. P. P., and Nichols, G. J. 1986. Thrust tectonic controls on alluvial sedimentation patterns, southern Pyrenees. In Allen, P. A., and Homewood, P., eds. Foreland basins. Int. Assoc. Sedimentol. Spec. Publ. 8:153160.

Markewich, H. W.; Pavich, M. J.; and Buell, G. R. 1990. Contrasting soils and landscapes of the Piedmont and Coastal Plain, eastern United States. Geomorphology 3:417-447.

Maynard, J. B. 1992. Chemistry of modern soils as a guide to interpreting Precambrian paleosols. J. Geol. 100: 279-289.

Nichols, G. J., and Hirst, J. P. 1998. Alluvial fans and fluvial distributary systems, Oligo-Miocene, northern Spain: contrasting processes and products. J. Sediment. Res. 68:879-889.

Pérez-Rivarés, F. J.; Garcés, M.; Arenas, C.; and Pardo, G. 2002. Magnetocronología de la sucesión miocena de la Sierra de Alcubierre (sector central de la Cuenca del Ebro). Rev. Soc. Geol. España 15:217-231.

Puigdefàbregas, C.; Muñoz, J. A.; and Vergès, J. 1992. Thrusting and foreland basin evolution in the south- 
ern Pyrenees. In McClay, K. R., ed. Thrust tectonics. London, Chapman \& Hall, p. 247-254.

Quirantes, J. 1978. Estudio sedimentológico y estratigráfico del Terciario continental de Los Monegros. Zaragoza, Spain, Institución Fernando El Católico (Consejo Superior de Investigaciones Científicas), Diputación Provincial de Zaragoza.

Retallack, G. J. 2000. Depth to pedogenic carbonate horizon as a paleoprecipitation indicator? comment. Geology 28:572-573.

. 2001. Soils of the past: an introduction to paleopedology (2nd ed.). Chichester, Blackwell Science.

- 2004. Late Oligocene bunch grassland and early Miocene sod grassland from central Oregon, USA. Palaeogeogr. Palaeoclimatol. Palaeoecol. 207:203-237.

Royer, D. L. 1999. Depth to pedogenic carbonate horizon as a paleoprecipitation indicator? Geology 27:11231126.

Sheldon, N. D. 2003. Pedogenesis and geochemical alteration of the Picture Gorge subgroup, Columbia River basalt, Oregon. Geol. Soc. Am. Bull. 115:13771387.

. 2006. Quaternary glacial-interglacial climate cycles in Hawaii. J. Geol. 114:367-376.
Sheldon, N. D., and Retallack, G. J. 2004. Regional paleoprecipitation records from the Late Eocene and Oligocene of North America. J. Geol. 112:487-494.

Sheldon, N. D.; Retallack, G. J.; and Tanaka, S. 2002. Geochemical climofunctions from North American soils and application to palaeosols across the EoceneOligocene boundary in Oregon. J. Geol. 110:687-696.

Sirvent, J.; Desir, G.; Gutierrez, M.; Sancho, C.; and Benito, G. 1997. Erosional rates in badland areas recorded by collectors, erosion pins and profilometer techniques (Ebro Basin, NE Spain). Geomorphology 18:61-75.

Soil Survey Staff. 1999. Keys to soil taxonomy (8th ed.). Soil Conservation Service. U.S. Department of Agriculture, Natural Resources Conservation Service. Blacksburg, VA, Pocahontas.

Van der Voo, R. 1993. Paleomagnetism of the Atlantic, Tethys and Iapetus oceans. Cambridge, Cambridge University Press, $411 \mathrm{p}$.

Zachos, J. C.; Pagani, M.; Sloan, L.; Thomas, E.; and Billups, K. 2001. Trends, rhythms, and aberrations in global climate $65 \mathrm{Ma}$ to present. Science 292:686-693. 